\title{
Measuring Performance of Halal Supply Chain Using Analytical Hierarchy Process (AHP) and Supply Chain Operations Reference (SCOR) 12.0 Approach: A Case Study
}

\author{
Qurtubi $^{1 *}$, Bagas Swardhana Putra ${ }^{1}$, Vembri Noor Helia ${ }^{1}$, Nasruddin Faisol ${ }^{2}$
}

\author{
${ }^{1 *}$ Department of Industrial Engineering Universitas Islam Indonesia, Indonesia \\ ${ }^{2}$ Department of Quantity Surveying Universiti Teknologi MARA, Malaysia \\ *Corresponding author.Email: qurtubi@uii.ac.id
}

\begin{abstract}
As one of the countries with the most populous Moslem in the world, it is undoubtedly that the halal aspect has become a vital concept in the everyday life of Indonesian people. In its effort to meet customers' necessities, one of the factors that could help the company in achieving its purpose is the ability of supply chain management. XYZ Supermarket is a company that operates in retail and is located in Yogyakarta. The objective of this research is to identify the performance of the supply chain in XYZ Supermarket for accommodating it with the best recommendation to improve the performance of the supply chain. The methods employed are Analytical Hierarchy Process (AHP) and Supply Chain Operations Reference (SCOR)" 12.0. Based on the research, it is found five main business processes, which are Plan, Source, Deliver, Return, and Enable. Besides, 27 metrics are available, and four of them align with Islamic values. After the entire metrics are analyzed by using Traffic Light System, there are 24 metrics identified with a green indicator, two metrics with a yellow indicator, and one metric with a red indicator. Overall, the performance value of the supply chain of XYZ Supermarket in the period of January-March 2021 is recorded as 97,91\%, which demonstrates great performance.
\end{abstract}

Keywords: AHP, SCOR, Halal Supply Chain, simulation

\section{INTRODUCTION}

The efforts to enhance the company's global competitiveness must be persistently maintained, hence collaboration with other companies should be initiated, which can influence the competitiveness [1]. Several things that have to be escalated are the integration and regulation of the company's supply chain [2]. The retail industry is counted as one of the progressive industries that are influenced by supply chain activities. The supermarket is one of the forms of the existed retail industry. The supermarket plays an important role as an intermediary between producers and costumers in the market [3]. The supply chain towards daily needs traditionally focuses on specific things, such as efficient cost reduction, as the effort to provide a massive number of products with low cost to customers [4]. The company should be able to integrate the internal activities by maintaining its integration with external parties, the integration with distributors and customers [5].
On the other hand, Indonesia is recorded as the country that is mostly occupied by Moslem. Based on the data collected by the Global Islamic Economy in 20182019 , which reaches $87,18 \%$ out of 232,5 million people. [6]. In Moslem's life, halal is defined as one of the vital concepts in living daily life. Halal is also stated as the standard of quality that meets the Islamic syar'i, to be implemented in every Moslem's activities [7]. Based on Al-Quran Surah An-Nahl (16): 114 stated that it is a must for people to consume food and beverages, which are halal and good. It affects the nutrition quality and the purity of the heart in living life. Therefore, it is important to review the entire hal-al traceability system as an effort to maintain the halal condition as well as its direct effect, in terms of determining the halal supply chain performance [8].

The management of the Halal Supply Chain is the new perspective that has been developed in the 2000s, It was encouraged by the ambition of companies to meet 
the demand of the Moslem community as costumers to ensure that everything consumed is halal, not merely its raw material but also the entire processes involved in the production [9]. Besides, the measurement of performance is crucial to be performed to identify whether the process is running appropriately as standard. Modifying the existing model of performance model in SCM, such as Balance Score Card, PRISM, IMPS, SCOR, and others by involving Islamic values indicators is considered able to incarnate the SCM halal balance [10].

$\mathrm{XYZ}$ is one of the companies that operate in retail and is located in Yogyakarta. As its development, until recently XYZ has established nine branches that scattered in several locations. XYZ provides daily goods, office, and school appliances, as well as writing tools. As one of the retail companies, XYZ always refers its activity to Islamic value, strongly. That was the main reason for selecting XYZ Supermarket as the object of the research entitled "Performance Measurement of Halal Supply Chain with Analytical Hierarchy Process (AHP) and Supply Chain Operations Reference (SCOR) 12.0 Approach."

The utilization of the SCOR method in this research is based on several considerations: (1) Able to map business performance in the supply chain to several parts, which are Plan, Source, Make, Deliver and Return, (2) Each business process has its Key Performance Indicator, and (3) It is considered as best practice in measuring the performance [11]. The measurement with the correct method is expected to help the XYZ Supermarket to identify the condition of its halal supply chain. Therefore, feedback is emerged to improve its future performance in the halal supply chain.

\subsection{Theoretical Background of Halal Supply Chain and Performance Measurement}

\subsubsection{Supply Chain Management}

The supply chain is explained as the integration and coordination of purchasing planning, production, distribution, and demand. It takes strategic decision-making, tactics, and operations. An optimization model is being developed to operate the activities in the supply chain [12]. Hence, a strategy of a flexible supply chain must be figured out to deal with dynamic changes. Therefore, to cope with the advanced challenge effectively, the existence of a smart supply chain is required [13].

Supply Chain Management (SCM) is focused on activities sequences that are integrated, started from supplier to end-customers. SCM becomes one of the important factors in the sustainability of an organization or company. Due to SCM, the company also deals with external matters such as collaboration with related partners, not only dealing with internal affairs.

\subsubsection{Halal Supply Chain Management}

Halal is defined as everything that is permitted or accepted by Moslems [14]. Talib [15] et al. stated that although the halal and haram concept refers more to food, yet recently it also has covered non-foods (such as pharmacy and cosmetics), and services (such as logistics, banking, and tourism).

In terms of the supply chain, there is a certain conventional supply chain that complies with Islamic law [16]. To ensure halal integrity, all requirements should be met, included upstream and downstream in the supply chain, besides the production process itself. The existence of a small amount of non-halal substance could revoke the halal status [17]. The protection and precaution actions must be involved to ensure the halal status of a product, even during the transportation process in the supply chain [18].

\subsubsection{Performance Measurement}

Performance measurement is crucial for supply chain management that covers the process for planning process management, coordination, and the control of material movement, spare parts, and products in the entire supply chain, from the suppliers to the end-customers [19].

One of the methods that could be employed to measure the performance of the supply chain in a company is Supply Chain Operations Reference (SCOR). SCOR is focused on the assessment and final process evaluation of the supply chain, in terms of its implementation result. The inclusive approach is tailored to understand, evaluate, and diagnose the performance of the supply chain. Three features are involved, which are the Performance Attributes, Metrics, and the Maturity of Process Maturity/Practices. Element, which is different from Level in the hierarchy of Process and Metric describes different aspects or different performance dimensions [20].

\section{METHODS}

The quantitative method is utilized in this research design. This method is selected due to data utilization is in the form of numbers and sourced directly from XYZ Supermarket, to be later analyzed. Hence, it could be highlighted as the result of an objective that is previously formulated. The collected data will be employed for data processing by using Supply Chain Operations Reference 
(SCOR), Analytical Hierarchy Process (AHP), and Traffic Light System (TLS) with the help of Microsoft Excel software.

The first step in the research process is the identification of the business process run by the company, in general. The second step is the pattern identification of the company's supply chain in detail, from the beginning to the end. The third plan is to map 6 main processes that existed in the supply chain activities, which include Plan, Source, Make, Deliver, Return, and Enable. Nevertheless, the processes involve only 5 , due to the absence of Make process in the designated company. The fourth step is the decomposition of performance metrics to be linked in sequence started from level-1, level-2, level-3, and so on that aligned with data derived from each performance indicator. Identification of halal performance metrics is also performed at this stage. After all performance indicator data are gathered, the fifth step is performing the weighting for each indicator of supply chain performance. This process is entirely performed by an expert, in this case, the branch manager from XYZ Supermarket. The sixth stage is performing the final score calculation by using the scoring system method. It is designed to identify the performance achievement for each metric. From the scoring system result, the last step is to identify the condition of each performance metric based on three indicator colors are used as a measurement, in which red represents unsatisfactory, yellow means marginal, and green means satisfactory.

\subsection{Supply Chain Operations Reference (SCOR)}

SCOR is defined as all commercial events related to the fulfillment of the demand of customers that includes plan, source, production, delivery, and return. It is also used to analyze the recent condition on the process and the corporates' purposes, to measure the performance in the operation process, and to compare the company's performance with standard data. It is later developed a metrics set and the best practice data that possibly applied by the companies to evaluate their supply chain performance [20]. The SCOR version 12.0 is employed in this research.

\subsection{Analytical Hierarchy Process (AHP)}

In terms of the supply chain, the supplier plays an important role and is inseparable from the process. It implies the importance of supplier selection as one of the issues in the recent supply chain [21]. The multi-criteria and technical decision-making processes are employed as the basis of Integration strategy and supplier selection
[22]. In implementing the multi-criteria analysis technique for decision making, Analytical Hierarchy Process (AHP) is the most frequently used method [23]. AHP method is utilized to provide score weight for each indicator of supply chain performance. This process is entirely performed by the branch manager of XYZ Supermarket. The weighting is conducted towards 3 metric levels that represent the whole supply chain performance.

\subsection{Scoring System and The Analysis of Traffic Light System}

The final score calculation for performance can be carried out by using the scoring system method to determine the existing score. Hence, the performance achievement of each metric can be figured out. Analysis of traffic light system is beneficial to improve the output quality through cost reduction, including to strengthen the supply chain performance [24]. The method of traffic light system analysis works similarly with the transportation traffic system [25]. In this research, the red color is valued $<60$ that indicates unsatisfactory, the yellow color is valued at 60-80 indicated the marginal performance, while the green color is valued $\geq 80$ that demonstrates satisfactory performance.

This research flow chart was created to make it easier to describe a more structured research flow. The following are the stages of research shown in the following flow chart: 


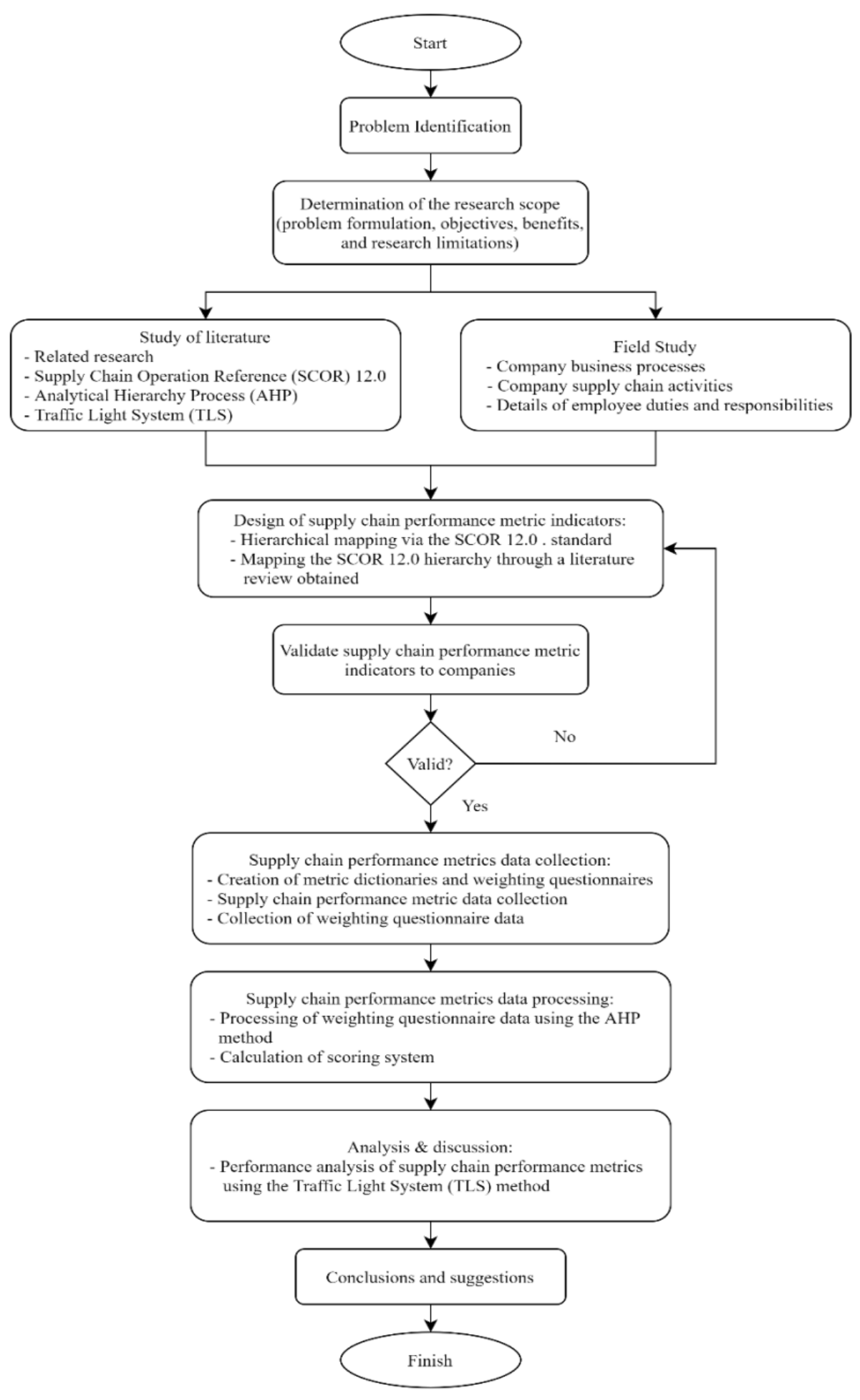

Figure 1. Research Flow 


\section{RESULTS AND DISCUSSION}

\subsection{Data Collection}

From the existing business process, business process mapping can be conducted later by using SCOR 12.0. As seen in Table 4.1, sub-processes occur at the process of Plan, consists of plan supply chain, plan source, plan deliver, and plan return. The process of Source consists of a sub-process of source-stocked products. The process of Deliver includes the sub-process of deliver retail product. While the process of Return consists of the sub-process of source return the defective product and deliver return defective product. Lastly, the process of Enable covers the sub-process of manage supply chain performance.

After mapping the business procedures, the metric of performance determination aligned with the condition of XYZ Supermarket is conducted. This metric determination is performed by using literature review and interviews. The literature review is carried out to identify the information related to performance measurement metrics that must be employed in the case of a retail company and its kind. Later, the validation should be performed by involving the branch manager from XYZ Supermarket to

Table 1. Performance Metrics SCOR 12.0

\begin{tabular}{|c|c|c|c|c|}
\hline No & Performance Metrics & Level 3 & Level 2 & Level 1 \\
\hline 1 & Inventory Days of Supply & AM & \multirow{2}{*}{ Plan Supply Chain } & \multirow{8}{*}{ Plan } \\
\hline 2 & Establish Supply Chain Plans Cycle Time & RS & & \\
\hline 3 & Establish Sourcing Plans Cycle Time & RS & \multirow{4}{*}{ Plan Source } & \\
\hline 4 & $\begin{array}{l}\text { Inspection of Halal Certification and Logo on the } \\
\text { Product }\end{array}$ & \multirow{3}{*}{$\mathrm{RL}$} & & \\
\hline 5 & Number of Halal Products & & & \\
\hline 6 & Warehouse Utilization & & & \\
\hline 7 & Establish Delivery Plans Cycle Time & RS & Plan Deliver & \\
\hline 8 & $\begin{array}{l}\text { Establish and Communicate Return Plans Cycle } \\
\text { Time }\end{array}$ & RS & Plan Return & \\
\hline 9 & $\%$ Orders/ Lines Processed Complete & \multirow{5}{*}{$\mathrm{RL}$} & \multirow{9}{*}{$\begin{array}{l}\text { Source Stocked } \\
\text { Product }\end{array}$} & \multirow{9}{*}{ Source } \\
\hline 10 & $\begin{array}{l}\% \text { Orders/ Lines Received On Time To Demand } \\
\text { Requirement }\end{array}$ & & & \\
\hline 11 & $\%$ Orders/ Lines Received with Correct Content & & & \\
\hline 12 & $\begin{array}{l}\text { Product Warranty Does Not Mix With Non-Halal } \\
\text { Products }\end{array}$ & & & \\
\hline 13 & No Usury Transaction & & & \\
\hline 14 & Receiving Product Cycle Time & \multirow{4}{*}{ RS } & & \\
\hline 15 & Verify Product Cycle Time & & & \\
\hline 16 & Transfer Product Cycle Time & & & \\
\hline 17 & Authorize Supplier Payment Cycle Time & & & \\
\hline 18 & \% Item Location Accuracy & $\mathrm{RL}$ & \multirow{5}{*}{$\begin{array}{l}\text { Deliver Retail Prod- } \\
\text { uct }\end{array}$} & \multirow{5}{*}{ Deliver } \\
\hline 19 & Receive Product Cycle Time & \multirow{4}{*}{ RS } & & \\
\hline 20 & Pick Product from Backroom Cycle Time & & & \\
\hline 21 & In-stock \% & & & \\
\hline 22 & Checkout Cycle Time & & & \\
\hline 23 & Return Rate & $\mathrm{RL}$ & $\begin{array}{l}\text { Source Return De- } \\
\text { fective Product }\end{array}$ & \multirow{4}{*}{ Return } \\
\hline 24 & Authorized Defective Return Cycle Time & \multirow{3}{*}{ RS } & \multirow{3}{*}{$\begin{array}{l}\text { Deliver Return De- } \\
\text { fective Product }\end{array}$} & \\
\hline 25 & Schedule Defective Return Receipt Cycle Time & & & \\
\hline 26 & Transfer Defective Product Cycle Time & & & \\
\hline 27 & $\begin{array}{l}\text { Performance Measurement Between Sell In and } \\
\text { Sell Out }\end{array}$ & $\mathrm{RL}$ & $\begin{array}{l}\text { Manage Supply } \\
\text { Chain Performance }\end{array}$ & Enable \\
\hline
\end{tabular}


identify the performance metrics that meet the actual condition

Based on the result of validation, 27 performance metrics fit the actual condition of XYZ Supermarket. From the total of 27 metrics, 4 of them are aligned with the Islamic values, which are the review of halal certification and the logo attachment on the product, the amounts of halal products, product warranty does not mix with non-halal products, and no usury transaction. To simplify the data processing process, the grouping of performance metrics based on the measurement attributes is initiated that covers reliability, responsiveness, and asset management, along with the formulation.

Table 2. The scoring of metrics performance with traffic light system

\begin{tabular}{|c|c|c|c|c|c|c|c|c|}
\hline NO & Matrics & Process & $\begin{array}{l}\text { Actual } \\
\text { value }\end{array}$ & $\begin{array}{l}\text { Min } \\
\text { value }\end{array}$ & $\begin{array}{l}\text { Max } \\
\text { value }\end{array}$ & SNORM & $\begin{array}{l}\text { Final } \\
\text { scoring }\end{array}$ & Score \\
\hline 1 & $\begin{array}{l}\text { Inspection of halal certification and logo } \\
\text { on the products }\end{array}$ & \multirow[t]{8}{*}{ Plan } & 2 & 1 & 2 & $100 \%$ & 0,055 & $5,54 \%$ \\
\hline 2 & Establish supply chain plans cycle time & & 2 & 1 & 2 & $100 \%$ & 0,055 & $5,54 \%$ \\
\hline 3 & Establish sourcing plans cycle time & & 1 & 1 & 2 & $100 \%$ & 0,026 & $1,3 \%$ \\
\hline 4 & $\begin{array}{l}\text { Inspection of halal certification and logo } \\
\text { on the products }\end{array}$ & & 100 & 0 & 100 & $100 \%$ & 0,013 & $1,27 \%$ \\
\hline 5 & Number of halal products & & 100 & 0 & 100 & $100 \%$ & 0,011 & $1,13 \%$ \\
\hline 6 & Warehouse utilization & & 5 & 1 & 5 & $100 \%$ & 0,002 & $0,20 \%$ \\
\hline 7 & Establish delivery pants cycle time & & 1 & 1 & 2 & $100 \%$ & 0,111 & $11,08 \%$ \\
\hline 8 & $\begin{array}{l}\text { Establish and communicate return plans } \\
\text { cycle time }\end{array}$ & & 4 & 2 & 7 & $60 \%$ & 0,018 & $1,69 \%$ \\
\hline 9 & $\%$ Orders/lines proceed complete & \multirow[t]{9}{*}{ Source } & 98,44 & 0 & 100 & $98,44 \%$ & 0,005 & $0,50 \%$ \\
\hline 10 & $\begin{array}{l}\text { \%Orders/lines received on time to de- } \\
\text { mand requirements }\end{array}$ & & 76,23 & 0 & 100 & $76,23 \%$ & 0,005 & $0,39 \%$ \\
\hline 11 & $\begin{array}{l}\text { \%Orders/lines received with correct con- } \\
\text { act }\end{array}$ & & 98,42 & 0 & 100 & $98,42 \%$ & 0,005 & $0,50 \%$ \\
\hline 12 & $\begin{array}{l}\text { Product warranty does not mix with non- } \\
\text { halal products }\end{array}$ & & 100 & 0 & 100 & $100 \%$ & 0,046 & $4,57 \%$ \\
\hline 13 & No usury transaction & & 100 & 0 & 100 & $100 \%$ & 0,046 & $4,57 \%$ \\
\hline 14 & Receiving product cycle time & & 1 & 0 & 1 & $100 \%$ & 0,035 & $3,54 \%$ \\
\hline 15 & Verify product cycle time & & 1 & 0 & 1 & $100 \%$ & 0,031 & $3,10 \%$ \\
\hline 16 & Transfer product cycle time & & 1 & 0 & 1 & $100 \%$ & 0,031 & $3,10 \%$ \\
\hline 17 & Authorized supplier payment cycle time & & 1 & 0 & 1 & $100 \%$ & 0,09 & $0,92 \%$ \\
\hline 18 & $\%$ item location accuracy & \multirow[t]{5}{*}{ Deliver } & 100 & 0 & 100 & $100 \%$ & 0,053 & $5,3 \%$ \\
\hline 19 & Received product cycle time & & 1 & 0 & 1 & $100 \%$ & 0,006 & $0,62 \%$ \\
\hline 20 & Pack products from backroom cycle time & & 5 & 1 & 5 & $100 \%$ & 0,02 & $0,21 \%$ \\
\hline 21 & In stock\% & & 5 & 1 & 5 & $100 \%$ & 0,02 & $2,24 \%$ \\
\hline 22 & Checkout cycle time & & 0,42 & 1,89 & 0 & $62 \%$ & 0,022 & 0,022 \\
\hline 23 & Return rate & \multirow[t]{4}{*}{ Return } & 0,0095 & 0 & 100 & $99,99 \%$ & 0,015 & $1,52 \%$ \\
\hline 24 & $\begin{array}{l}\text { Authorized defective return received cycle } \\
\text { time }\end{array}$ & & 1 & 0 & 1 & $100 \%$ & 0,023 & $2,33 \%$ \\
\hline 25 & $\begin{array}{l}\text { Schedule defective return received cycle } \\
\text { time }\end{array}$ & & 1 & 0 & 1 & $100 \%$ & 0,05 & $0,46 \%$ \\
\hline 26 & $\begin{array}{l}\text { Transfer defective return received cycle } \\
\text { time }\end{array}$ & & 1 & 0 & 1 & $100 \%$ & $0,18 \%$ & $1,78 \%$ \\
\hline 27 & $\begin{array}{l}\text { Performance measurement between sell } \\
\text { in and sell out }\end{array}$ & enable & 98,82 & 0 & 100 & $98,82 \%$ & 0,328 & $32,42 \%$ \\
\hline \multicolumn{6}{|c|}{\begin{tabular}{|ll} 
& Total
\end{tabular}} & $96 \%$ & 1 & $97,91 \%$ \\
\hline
\end{tabular}




\subsection{Numerical Results}

Scoring system by using normalization process, and later be continued with the analysis of Traffic Light System to reveal the condition of each metric based on three different color indicators as assessment, which are red, yellow, and green. Red indicates that the snorm de boer normalization score is in the range of $\leq 60$, it reveals the unsatisfying performance. The yellow color indicates that the snorm de boer normalization score is in the range of 60 to $<80$, which means that the matric has marginal performance. Lastly, the green indicator demonstrates the snorm de boer normalization score in the range of $\geq$ 80 , which shows excellent metric performance. Based on the identification result by employing the method of traffic light system, it could be notified that from the existing 27 metrics, there are 24 metrics with green light indicator, 2 metrics with yellow indicator, and 1 metric with red indicator.

It is also found the supply chain performance's final score of in XYZ Supermarket for 97,91\%. The result reveals that the supply chain performance on the selected distributor, as one of the biggest distributors in XYZ Supermarket is considered as very good and affects toward overall company's performance. Yet, several improvements could be exposed to performance metrics that are still unable to attain green indicators, later it could enhance the company's supply chain performance, entirely.

\subsection{Graphical Results}

The scoring result for AHP weighting on every process indicates that the gap of score between the company's target and actual data is small. It can be calculated that the gap in the process of Plan is $0.72 \%$, the process of Source is $0.14 \%$, the process of Deliver is $0.85 \%$, the process of Return is $0.00 \%$, and the process of Enable is $0.39 \%$. Those figures demonstrate that the performance of each process is very good with the small score of gap.

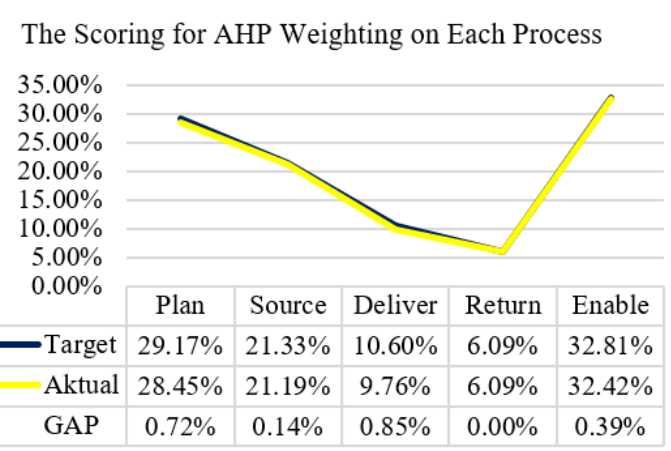

Figure 2 The scoring for AHP weighting on each process

\subsection{Proposed Improvements}

From the available 27 performance metrics, 24 metrics show satisfactory performance demonstrated with green indicator, 2 metrics show marginal performance with yellow indicator, and 1 metric indicated with red indicator demonstrates the unsatisfactory performance.

The best recommendations provided for a metric of Establish and Communicate Return Plans Cycle Time, are (1) routine and regular identification on each product that needs return process, hence the claim for the replacement product can be executed immediately, and (2) intensive coordination with the distributor for the faster claim process. Next, the best recommendation for a metric of \% Orders/Lines Received On-Time to Demand Requirement is to select an alternative distributor if the main product distributor is unable to meet the order as a predetermined PO. Finally, the recommendations for a metric of Checkout Cycle Time are (1) The existence of a debit machine for every payment counter, hence it will shorten the distance for accessing the machine and avoid taking turns with the cashier from other counters, and (2) special training for the cashier to eliminate or disregard the ineffective movements that potentially could cause transactions to be extended

\section{CONCLUSION}

There are five main business processes run by XYZ Supermarket, which are Plan, Source, Deliver, Return, and Enable. Later, it is obtained 27 performance metrics, of which four of them are aligned with Islamic values. Those four metrics are inspection of halal certification and logo on the product, the number of halal products, product warranty does not mix with non-halal products, and no usury transaction.

From the utilization of 27 performance metrics, 24 metrics indicate satisfactory performance with green indicator, 2 metrics show marginal performance with yellow indicator, and 1 metric indicates unsatisfactory performance with red indicator.

Overall, the final score for supply chain performance in XYZ Supermarket is calculated as $97,91 \%$. It reveals that the supply chain performance for the selected distributor, as one of the biggest distributors in XYZ Supermarket, is great and gives a significant impact on the company's performance, entirely.

\section{REFERENCES}

[1] M.-C. Huang, G.-F. Yen and T.-C. Liu, "Reexamining supply chain integration and the supplier's performance relationships under uncertainty," Supply Chain Management: An International Journal, vol. 19, no. 1, pp. 64-78, 2014. 
[2] D. R. Goeltz, "Globalization and Hypercompetition - Drivers, Linkages, and Industry Differences," Journal of International Business and Cultural Studies , vol. 8, pp. 1-15, 2014.

[3] M. Rasoly, "A Study on Consumer Satisfaction of Supermarket in Mysore City, Mysore," International Journal of Research in Business Studies and Management, vol. 5, no. 5, pp. 23-29, 2018.

[4] H. C. Dreyer, N. Swahn, K. Kiil and J. O. Strandhagen, "The Responsiveness of Food Retail Supply Chains: A Norwegian Case Study," in IFIP International Conference on Advances in Production Management Systems, 2015.

[5] J. Sutanto and A. Japutra, "The Impact of Supply Chain Integration and Trust on Supply Chain Performance: Evidence from Indonesia Retail Sector," International Journal of Economics and Business Administration, vol. 9, no. 1, pp. 211-224, 2021.

[6] Global Islamic Economy Report, "State of the Global Islamic Economy Report (Driving The Islamic Economy Revolution 4.0)," Global Islamic Economy Report, 2019.

[7] A. M. Bohari, C. W. Hin and N. Fuad, "An analysis on the competitiveness of halal food industry in Malaysia: an approach of SWOT and ICT strategy," Malaysia Journal of Society and Space, 2013.

[8] N. Zainuddin, A. M. Saifudin, N. Deraman and A. A. Osman, "The Effect of Halal Traceability System on Halal Supply Chain Performance," International Journal of Supply Chain Management, vol. 9, no. 1, pp. 490-498, 2020.

[9] M. H. Zulfakar, M. MohamedAnuar and M. S. AbTalib, "Conceptual Framework on Halal Food Supply Chain Integrity Enhancement," Kuala Lumpur, 2012.

[10] Harwati and A. Y. Pettalolo, "Halal Criteria in Supply Chain Operations Reference (SCOR) for Performance Measurement: A case Study," IOP Conference Series: Materials Science and Engineering, 2019.

[11] P. Akkawuttiwanich and P. Yenradee, "Fuzzy QFD Approach for Managing SCOR Performance Indicators," Computers \& Industrial Engineering, vol. 122, pp. 189-201, 2018.

[12] Y. KOCAOĞLU, A. T. GÜMÜŞ and B. KOCAOĞLU, "Supply Chain Optimization Studies: A Literature Review and Classification," Doğuş Üniversitesi Dergisi, vol. 19, no. 1, pp. 79-98, 2018.

[13] L. Wu, X. Yue, A. Jin and D. C. Yen, "Smart Supply Chain Management: a Review and Implications for Future Research," The International Journal of Logistics Management, vol. 27, no. 1, pp. 395-417, 2016.
[14] H. M. Awan, A. Nabeel and Z. Haider, "Factors Affecting Halal Purchase Intention - Evidence from Pakistan's Halal Food Sector," Management Research Review, vol. 38, no. 6, pp. 640-660, 2015.

[15] A. B. A. H. M. H. Z. Mohamed Syazwan Ab Talib, "Halal Supply Chain Critical Success Factors: a Literature Review," Journal of Islamic Marketing, vol. 6, pp. 44-71, 2015.

[16] E. N. Omar, H. S. Jaafar and M. R. Osman, "Assessing Halalan-Toyyiban Food Supply Chain In The Poultry Industry," Procedia - Social and Behavioral Sciences, pp. 1-9, 2012.

[17] A. M. Saifudin, S. N. Othman and E. M. Elias, "Exploring in Setting a Model for Islamic Supply Chain in Malaysia," International Review of Management and Marketing, vol. 7, pp. 95-102, 2017.

[18] R. b. M. Ismail, M. Mustafar and S. N. Othman, "Genetically Modified Food in Malaysia Halal Food Supply Chain: An Insight," International Journal of Supply Chain Management, vol. 7, 2018.

[19] E. Simchi-Levi, D. Simchi-Levi and P. Kaminsky, Designing and Managing the Supply Chain : Concepts, Strategies and Case Studies, 3rd ed., New York: McGraw Hill, 2008.

[20] APICS Supply Chain Council, SCOR TRAINING : Introduction to the SCOR Supply Chain Operations Reference Model Version 12: Overview, Chicago: APICS Supply Chain Council, 2017.

[21] J. Rezaei, P. B.M.Fahim and L. Tavasszy, "Supplier Selection in the Airline Retail Industry Using a Funnel Methodology: Conjunctive Screening Method and Fuzzy AHP," Expert Systems with Applications, vol. 41, no. 18, pp. 8165-8179, 2014.

[22] G. D. Whitten, K. W. Green and P. J. Zelbst, "Triple-A Supply Chain Performance," International Journal of Operations \& Production Management, vol. 32, no. 1, pp. 28-48, 2012.

[23] N. Sael, T. Hamim and F. Benabbou, "Implementation of the Analytic Hierarchy Process for Student Profile Analysis," International Journal of Emerging Technologies in Learning (iJET), vol. 14, no. $15,2019$.

[24] M. F. Hanif, H. T. Sadia, M. H. Chaion, M. A. S. Rafi, M. J. Uddin, T. Islam and M. R. Repon, "Quality Improvement in Readymade Garments Industry by Traffic Light System," Journal of Textile Engineering \& Fashion Technology, vol. 6, no. 3, pp. 90-93, 2020.

[25] M. M. Islam and M. S. Rahman, "Enhancing lean supply chain through traffic light quality management system," Management Science Letters, vol. 3, pp. 867-878, 2013. 